\title{
PENGAWASAN TEKNIS PENATAAN TAMAN JALUR HIJAU DI KECAMATAN BOGOR TIMUR, KOTA BOGOR JAWA BARAT
}

\author{
Andrianto Kusumoarto ${ }^{1}$, Rahmat Rejoni ${ }^{2}$ \\ ${ }^{1}$ Universitas Indraprasta PGRI, Program Studi Arsitektur \\ andrianto.kusumoarto@unindra.ac.id \\ ${ }^{2}$ Universitas Indraprasta PGRI, Program Studi Arsitektur \\ rahmat.rejoni@unindra.ac.id
}

\begin{tabular}{|c|c|}
\hline \multicolumn{2}{|c|}{ Informasi artikel } \\
\hline $\begin{array}{l}\text { Sejarah } \\
\text { artikel: }\end{array}$ & \\
\hline Diterima & 16 Februari 2021 \\
\hline Revisi & 26 Maret 2021 \\
\hline Dipublikasikan & 30 Maret 2021 \\
\hline
\end{tabular}

\section{Kata kunci:}

Jalur sirkulasi pejalan kaki

Pembangunan taman jalur hijau

Pengawasan teknis

Sarana dan prasarana jalan

Manajemen lanskap

\begin{abstract}
ABSTRAK
Wilayah Bogor Timur merupakan pusat Kota Bogor merupakan salah satu wilayah sangat aktif terutama saat hari dan jam kerja. Jalur sirkulasi kendaraan bermotor di Kelurahan Baranangsiang merupakan salah satu jalur sirkulasi sangat padat. Kepadatan juga terjadi di jalur-jalur pejalan kaki. Keadaan ini mendorong Pemerintah Kota Bogor untuk membangun jalur pejalan kaki yang nyaman dan mengatur rute jalur pergerakan pejalan kaki. Jalur sirkulasi kendaraan bermotor dan jalur hijau dipisahkan oleh jalur pejalan kaki. Kegiatan pengawan teknis penataan taman jalur hijau ini akan dilakukan di Jl. Padi Kelurahan Baranangsiang. Tujuan dari kegiatan ini adalah melakukan pengawasan teknis penataan taman jalur hijau. Metode yang digunakan adalah perencanaan pengawasan teknis dalam manajemen lanskap. Melalui pengawasan teknis yang dilakukan maka dapat dicapai pelaksanaan pembangunan taman jalur hijau yang efisiens dalam biaya, efektif dalam pekerjaan, dan memenuhi standar mutu kerja dan bahan, serta pelaksanaan pekerjaan yang tepat waktu. Keberadaan jalur hijau ini selain bernilai estetik juga berfungsi sebagai tempat pemberhentian sementara pejalan kaki.
\end{abstract}

Key word:

Pedestrian path

Green way park development

Engineering supervision

Road facilities and infrastructure

Landscape management

\begin{abstract}
The East Bogor region is the center of Bogor City, which is one of the most active areas, especially during working days. The motorized vehicle circulation route in Baranangsiang Village is one of the very dense circulation routes. Overcrowding also occurs on the pedestrian path. This situation encourages the Bogor City Government to build comfortable pedestrian paths and regulate pedestrian movement routes. The motorized vehicle circulation lane and the green way are separated by a pedestrian path. Engineering supervision activities of green way park arrangement will be carried out on Jl. Padi, Baranangsiang Village. The purpose of this activity is to supervise the technical arrangement of the green way park. The method used is technical surveillance planning in landscape management. Through the technical supervision carried out, it can be achieved the implementation of the construction of a green way park that is efficient in cost, effective in work, and meets quality standards of work and materials, as well as the execution of work on time. Besides having aesthetic value, the existence of this green way also functions as a temporary stopping area for pedestrians.
\end{abstract}

\section{PENDAHULUAN}

Kota Bogor merupakan kota yang memiliki tingkat kunjungan wisata yang baik. Sarana dan prasarana untuk kunjungan wisata ini disiapkan sangat baik oleh Pemerintah Kota Bogor terlebih Kota Bogor dapat dicapai dari kota-kota lain di sekitarnya dengan sangat mudah. Sarana transportasi dalam dan keluar Kota Bogor pun beragam. Salah satu sarana yakni sarana pejalan kaki termasuk jalur sirkulasi yang banyak digunakan. Kenyamanan dalam berjalan kaki juga diperoleh dengan hadirnya taman-taman di jalur hijau dimana berada di sebelah jalur pejalan kaki tersebut.

Jalur Jl. Padi merupakan salah satu jalur jalan kendaraan bermotor dan jalur pejalan kaki yang sangat aktif terutama saat hari dan jam kerja. Jalur sirkulasi kendaraan bermotor merupakan salah satu jalur sirkulasi cukup padat karena merupakan aksesibilitas alternatif dari jalan tol ke arah Kota Bogor. Keadaan ini mendorong Pemerintah Kota Bogor untuk membangun jalur pejalan kaki yang nyaman 
dengan menghadirkan taman di jalur hijau jalan. Keberadaan taman sudut jalan kota di jalur hijau diharapkan dapat memperlunak kesan terhadap suasana lingkungan jalur jalan yang digunakan oleh pengguna jalan.

Pembangunan jalur hijau diharapkan berfungsi untuk melunakkan kesan struktur jalan kendaraan bermotor dan jalur pejalan kaki sehingga memberikan rasa nyaman, selain itu juga dapat mengurangi polutan yang dikeluarkan dari kendaraan bermotor. Kesan estetik juga akan ditampilkan oleh warna, bentuk dan tekstur tanaman (Carpenter et al, 1975).

Pembangunan taman sudut kota yang dilakukan oleh Pemerintah Kota Bogor memerlukan pengawasan teknis berbasiskan ilmu dan keteknikan praktis sehingga bahan yang digunakan, mutu hasil pekerjaan, dan waktu untuk menyelesaikan pekerjaan dapat memenuhi keinginan dari Pemerintah Kota Bogor. Berdasarkan penelitian yang sudah dilakukan sebelumnya tentang analisis standarisasi pengawasan terhadap pembangunan kawasan taman kota, dikatakan bahwa pengawasan mampu mempengaruhi pembangunan taman kota sebesar 59,84\% (Gustiana, 2017). Sehingga Kegiatan ini bertujuan melakukan pengawasan teknis taman sudut kota, jalur hijau Jl. Padi, Kota Bogor untuk dapat menhasilkan kualitas taman yang lebih baik.

\section{METODOLOGI}

Metode perencanaan pengawasan teknis yang digunakan adalah perencanaan pengawasan teknis dalam manajemen lanskap (Motloch, 2001; Booth, 1983; Munandar \& Kusumoarto dalam Munandar et al, 2020). Perencanaan teknis ini berkenaan dengan manajemen pengawasan terhadap pelaksanaan pembangunan taman jalur hijau. Tahapan yang dilakukan untuk kegiatan ini adalah : 1 . Inventarisasi lokasi pembangunan taman sudut kota di jalur hijau; 2. Analisis perencanaan pelaksanaan pembangunan taman sudut kota di jalur hijau; 3. Perencanaan pengawasan teknis pelaksanaan pembangunan taman sudut kota di jalur hijau; 4. Pelaporan (Booth, 1983; Starke \& Simonds, 2013).

1. Inventarisasi Lokasi Pembangunan Taman Sudut Kota, Jalur Hijau Jl. Padi

Lokasi pembangunan taman jalur hijau perlu diketahui secara rinci tentang situasi dan kondisinya. Inventarisasi yang dilakukan juga dilakukan untuk mengetahui panjang dan lebar lahan untuk membangun taman jalur hijau, dan membangun jalur jalan setapak dan fasilitas lainnya di taman jalur hijau tersebut.

2. Analisis Perencanaan Pelaksanaan Pembangunan Taman Sudut Kota, Jalur Hijau Jl. Padi Kegiatan ini mengidentifikasi potensi dan permasalahan tapak berkenaan dengan rencana pembangunan taman jalur hijau. Setiap potensi yang ada dimanfaatkan secara optimal dan setiap permasalahan yang ada diberikan solusi alternatif pemecahan permasalahannya. Di dalam kegiatan ini diberikan solusi yang terbaik dan pemanfaatan yang terbaik.

3. Perencanaan Pengawasan Teknis Pelaksanaan Pembangunan Taman Sudut Kota, Jalur Hijau Jl. Padi Pembuatan perencanaan pengawasan berawal dari adanya solusi terbaik untuk kegiatan tersebut. Kegiatan perencanaan pengawasan yang dikemukan berlandaskan kepada kemudahan secara teknis dan keberlanjutan kegiatan yang telah direncanakan secara teknis. Perencanaan pengawasan teknis pembangunan taman jalur hijau memberikan peluang adanya pengorganisasian pelaksanaan pembangunan ruang terbuka hijau dalam bentuk taman jalur hijau jalan. Perencanaan dimaksudkan agar kegiatan pembangunan yang dilakukan dapat tepat waktu, efisien dalam pengeluaran biaya, dan efektif dalam melakukan pekerjaan dan bermutu untuk mencapai hasil pembangunan yang sesuai dengan rencana dan desain yang dibuat.

4. Pelaporan Pengawasan Teknis Pelaksanaan Pembangunan Taman Sudut Kota, Jalur Hijau Jl. Padi 
Kegiatan pelaporan pelaksanaan pengawasan teknis pembangunan taman jalur hijau meliputi : 1) pembuatan rencana jadwal kegiatan; 2) pengisian form laporan kegiatan harian, penggunaan peralatan harian, penggunaan bahan harian, penggunaan tenaga kerja harian; dan 3) pembuatan laporan harian, mingguan dan bulanan.

\section{HASIL DAN PEMBAHASAN}

\section{Kondisi Tapak}

Lokasi taman sudut kota (pocket park) awalnya merupakan sebidang lahan milik Pemerintah Kota Bogor yang diusahakan oleh beberapa orang untuk jual beli barang. Lokasinya tepat di sudut simpang tiga Jl. Padi (arah Permukiman Bogor Lake Side) (Gambar 1).

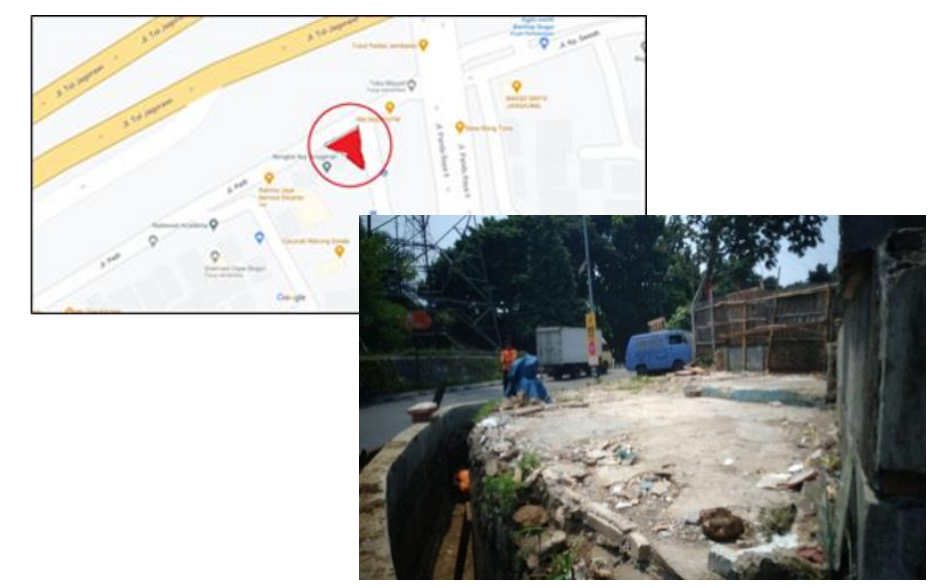

Gambar 1. Lokasi pengawasan teknis pembangunan taman jalur hijau Jalan Padi Sumber: Dokumentasi Pribadi (2020)

\section{Visual}

Ke arah utara lokasi terlihat visual Jalan Tol Jagorawi. Ke arah timur terlihat fly over R3. Ke arah barat terlihat perkampungan penduduk kota. Ke arah lokasi taman sudut kota sendiri terlihat tanah kosong setelah dilakukan pengambilan tanah milik Pemerintah Kota Bogor (Gambar 2).

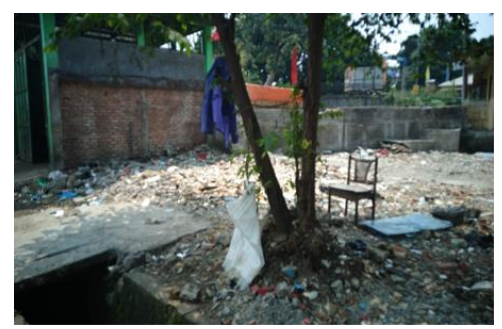

Gambar 2. Visual lokasi rencana taman sudut kota, jalur hijau Jl. Padi Sumber: Dokumentasi Pribadi (2020)

\section{Arah dan Jalur Sirkulasi}

Jalur sirkulasi utama yang berada di dekat taman sudut kota jalur hijau Jl. Padi adalah jalur kendaraan bermotor (mobil dan motor) dua arah. Terdapat jalur penghubung pejalan kaki dua arah yang telah berada pada kondisi yang kurang baik.

Pengguna pejalan kaki sebelum dibangun taman sudut kota ini mengalami kesulitan untuk melintas, sehingga sering terlihat pejalan kaki menggunakan badan jalan kendaraan bemotor. Hal ini 
cukup membahayakan karena lalu lintas kendaraan bermotor yang cukup padat di sekitar lokasi tersebut. Pejalan kaki mengharapkan adanya lintasan jalur pejalan kaki yang dapat memperpendek jarak.

\section{Konsep Perencanaan Pembangunan}

Konsep perencanaan pembangunan yakni "Taman Sudut Kota Jl. Padi yang Nyaman dan Aman", dimana pembangunan taman bertujuan utamanya mewadahi aktivitas pejalan kaki yang aman dan nyaman. Tujuan lainnya adalah untuk mengoptimalkan fungsi lahan-lahan jalur hijau Pemerintah Kota Bogor, serta berfungsi untuk sebagai tempat istirahat pejalan kaki dan masyarakat sekitar (rest area).

Dalam menerapkan konsep di atas, maka pelaksana pembangunan harus memahami konsep yang diinginkan. Prinsip keamanan dan kenyamanan merupakan hal yang utama. 3 (tiga) hal yang target tercapainya pembangunan taman sudut kota adalah : 1) perlintasan sirkulasi pejalan kaki yang efesien, 2) adanya tempat istirahat, dan 3) perbaikan kualitas lingkungan.

\section{Perencanaan Pelaksanaan Pembangunan Taman Sudut Kota, Jalur Hijau Jl. Padi}

Pembangunan taman sudut kota jalur hijau Jl. Padi harus memiliki prinsip pembangunan yang bermutu, efisien, dan tepat waktu. Prinsip ini diterapkan mulai pekerjaan pengadaan alat dan bahan, penempatan para pekerja, pelaksanaan pekerjaan, penyelesaian pekerjaan, serah terima pekerjaan hingga pelaporan pekerjaan. Pekerjaan pembangunan taman sudut kota ini terdiri dari beberapa tahap yakni : 1) pekerjaan persiapan (9,83\%), 2) pekerjaan penanaman (45,36\%), dan 3) pekerjaan hardscape $(44,81 \%)$. Pekerjaan tersebut dilakukan selama 5 minggu. Pekerjaan persiapan direncanakan secara bertahap pada minggu pertama dan minggu ke dua (Gambar 3). Pekerjaan penanaman direncanakan pada minggu ke dua hingga minggu ke empat. Pekerjaan hardscape direncanakan pada minggu ke empat hingga minggu ke lima.

\begin{tabular}{|c|c|c|c|c|c|c|c|c|c|}
\hline \multirow{3}{*}{ No } & \multirow{3}{*}{\multicolumn{2}{|c|}{ JENIS PEKERJAAN }} & \multirow{3}{*}{ Вовот \% } & \multicolumn{5}{|c|}{ HARI DAN MINGGU KE- } & \multirow{3}{*}{ KETERANGAN } \\
\hline & & & & 1 & 2 & 3 & 4 & 5 & \\
\hline & & & & $1-7$ & $8-14$ & $15-21$ & $22-28$ & $29-30$ & \\
\hline \multicolumn{10}{|c|}{ I PEKERJAAN PERSIAPAN } \\
\hline & & TOTAL PEKERJAAN PERSIAPAN & 9.83 & 1.97 & 1.97 & 1.97 & 1.97 & 1.97 & \\
\hline \multirow[t]{2}{*}{ ॥ } & PEKERJAAN P & ANAMAN & & & & & & & \\
\hline & & TOTAL PEKERJAAN PENANAMAN & 45.36 & - & - & & 15.12 & 15.12 & \\
\hline \multirow[t]{2}{*}{ IIII } & \multicolumn{2}{|c|}{ PEKERJAAN HARDSCAPE } & & & & & & & \\
\hline & & TOTAL PEKERJAAN HARDSCAPE & 44.81 & $\Longrightarrow$ & 5.98 & 6.42 & 12.59 & 9.67 & \\
\hline \multicolumn{3}{|c|}{ BOBOT RENCANA } & 100.00 & 1.97 & 7.95 & 23.51 & 29.68 & 26.76 & \\
\hline \multicolumn{3}{|c|}{ AKUMULASI BOBOT RENCANA } & & 7.05 & 20.08 & 43.58 & 73.25 & 100.00 & \\
\hline \multicolumn{3}{|c|}{ REALISASI BOBOT RENCANA (\%) } & & 8.80 & 19.17 & 35.33 & 36.21 & 0.50 & \\
\hline \multicolumn{3}{|c|}{ REALISASI AKUMULASI BOBOT RENCANA (\%) } & & 8.80 & 27.97 & 62.32 & 96.35 & 100.00 & \\
\hline & DEVIASI (\%) & & & -1.75 & -7.89 & -18.74 & -23.10 & 0.00 & \\
\hline \multicolumn{3}{|c|}{ KETERANGAN : } & \multicolumn{2}{|c|}{ Perencanaan } & & & & & \\
\hline & & & \multicolumn{3}{|c|}{ : Realisasi berdasarkan monitoring dilapangan } & & & & \\
\hline
\end{tabular}

Gambar 3. Rencana pelaksanaan pekerjaan taman sudut kota, jalur hijau JL. Padi

Pekerjaan persiapan yang direncanakan dilakukan adalah : 1) pemasangan papan nama kegiatan (0,32 \%), 2) pengadaan listrik dan air kerja (0,83\%), 3) pekerjaan bongkaran tanah cadas (5,90 $\%)$, 4) pekerjaan pembersihan lahan, saluran drainase, pembuangan puing dan sampah sisa pekerjaan ( $1,67 \%$ ), dan 5) pekerjaan penyelenggaraan $\mathrm{K}_{3}$ (termasuk pencegahan pandemi Covid-19 (1,11\%). Bobot pekerjaan yang terbesar adalah pekerjaan bongkaran tanah cadas. Dalam hal untuk minggu pertama 
pelaksanaan pekerjaan direncanakan fokus pada pekerjaan bongkaran tanah cadas yang berimplikasi kepada penempatan tenaga kerja dan alat-alatnya.

Pekerjaan penanaman yang direncanakan adalah 1) pemberian tanah urug (11,72\%), 2) pemberian pupuk kompos (0,69\%), 3) penanaman pohon bungur 1,09\%), 4) penanaman pohon pisang kipas (2,14 \%), 5) penanaman pisang hias calatea (5,74\%), 6) penanaman melati jepang (1,60\%), 7) penanaman plumbago (1,39 \%), 8) penanaman soka pink Bangkok (2,85\%), 9) penanaman kosandra oranye (3,24\%), 10) penanaman tecomaria yellow (4,02\%), 11) penanaman lantana golden (0,36 \%), 12$)$ penanaman canna black night (4,92\%), 13) penanaman bakung lele (1,84\%), dan 14) penanaman rumput gajah mini $(3,74 \%)$. Pekerjaan urugan tanah memiliki volume yang paling besar. Hal ini memperlihatkan bahwa tanah yang berada di lokasi berada dalam kondisi yang kurang baik sebagai media tanam. Jenis tanaman yang banyak digunakan adalah calatea, canna black night, tecomaria yellow dan rumput gajah mini.

Pekerjaan hardscape yang direncanakan adalah 1) pekerjaan edging pembatas, 2) pekerjaan jalan setapak, 3) pekerjaan lampu taman, 4) pekerjaan perapihan jalan akses, 5) pekerjaan perapihan sumur, 6) pekerjaan mesin/pompa air, rumah pompa, kran air dan pipa air include instalasi, dan 7) pekerjaan pembuatan pot beton minimalis fin.aci profil $1 \mathrm{~m} \times 1 \mathrm{~m} \times 1 \mathrm{~m}$. Pekerjaan edging pembatas meliputi : 1) pekerjaan galian tanah (0,30 \%), 2) pekerjaan pondasi batu belah (4,53 \%), 3) pekerjaan plesteran $1 \mathrm{pc}: 3 \mathrm{pp}$ tebal $15 \mathrm{~mm}(3,07 \%)$, 4) pekerjaan acian (1,80\%), 5) pekerjaan pengecatan (cat eksterior) (0,46\%). Pekerjaan jalan setapak (paving block) meliputi : 1) pekerjaan galian tanah (1,38\%), 2) pekerjaan urugan sirtu dan pemadatan (0,80\%), 3) pekerjaan pemasangan paving block natural 6 $\mathrm{cm}$ (sudah termasuk abu batu) $(6,90 \%), 4)$ pekerjaan pemasangan $1 / 2$ bata $1: 4$ untuk pembatas $(0,92$ \%), 5) pekerjaan plesteran $1 \mathrm{pc}: 3 \mathrm{pp}$ tebal $15 \mathrm{~mm}(1,04 \%), 6)$ pekerjaan acian $(0,61 \%), 7)$ pekerjaan pengecataan pembatas (cat eksterior) (0,31\%). Pekerjaan lampu taman meliputi : 1) pemasangan jaringan bawah lampu sorot pohon (4,34 \%), 2) pemasangan pondasi dan lampu led sorot $50 \mathrm{w}$ panggung (12,90 \%), 3) penyambungan listrik ke panel eksisting (0,97\%). Pekerjaan perapihan jalan akses meliputi : 1) pekerjaan plesteran $1 \mathrm{pc}$ : pp tebal $15 \mathrm{~mm}$ (0,27\%), 2) pekerjaaan acian (0,16\%). Pekerjaan perapihan sumur ( 1 set pembatas dinding bata dan penutup plat beton) (0,56\%). Pekerjaan mesin/pompa air meliputi : 1) pekerjaan mesin air sumur dalam $40 \mathrm{~m}(1,39 \%), 2)$ pekerjaan rumah pompa (kerangkeng) (0,42\%), dan 3) pekerjaan kran dan pipa air termasuk instalasi (0,56\%). Pekerjaan pot beton minimalis fin.aci profil $1 \mathrm{~m} \times 1 \mathrm{~m} \times 1 \mathrm{~m}(1,11 \%)$.

\section{Pelaksanaan Pembangunan Taman Sudut Kota, Jalur Hijau Jl. Padi}

Pembangunan taman sudut kota dilaksanakan mulai bulan Agustus hingga bulan September 2020 yang meliputi tiga kegiatan utama selama 5 (lima) minggu). Pada minggu pertama pelaksanaan kegiatan telah menyelesaikan 8,8 \% dari seluruh kegiatan. Pada minggu kedua sebanyak 19,17\%. Pada minggu ketiga sebanyak 35,33\%. Pada minggu keempat sebanyak 36,21\%, dan pada minggu kelima sebanyak $0,50 \%$.

Pembangunan taman sudut kota diawali dengan pembersihan lahan (Gambar 4), kemudian dilanjutkan dengan pengukuran tapak dan pengukuran tinggi permukaan lantai dan rumput. Pekerjaan pelaksanaan yang dimulai terlebih dahulu adalah pekerjaan persiapan yakni : 1) pemasangan paman nama kegiatan (Gambar 5), 2) pengadaan listrik dan air kerja, 3) pekerjaan bongkaran tanah cadas, 4) pekerjaan pembersihan lahan, saluran drainase, pembuangan puing dan sampah sisa pekerjaan, dan 5) pekerjaan penyelenggaraan $\mathrm{K}_{3}$. 


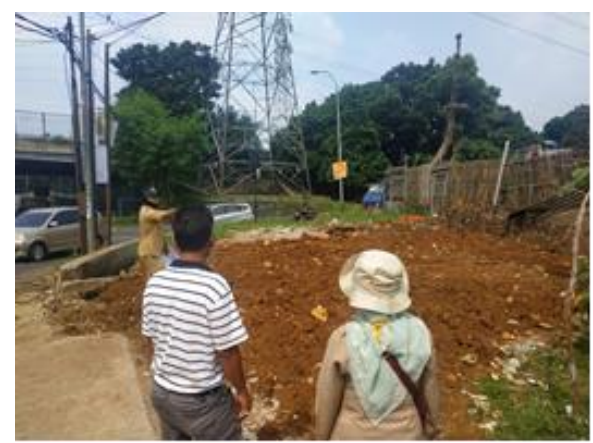

Gambar 4. Pekerjaan pembersihan lahan Sumber: Dokumen pribadi (2020)

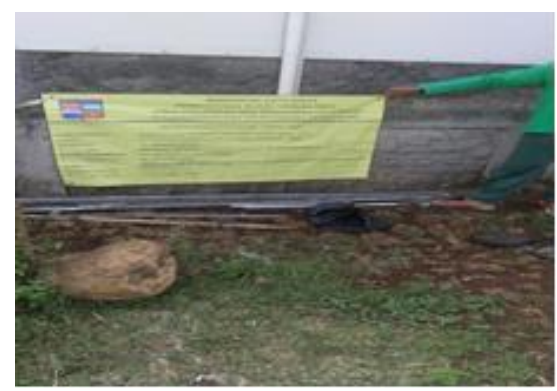

Gambar 5. Pekerjaan pemasangan papan nama kegiatan Sumber: Dokumen pribadi (2020)

Setelah pembongkaran tanah cadas dan pembersihan lahan, maka dilakukan pengukuran ketinggian permukaan jalan, ketinggian permukaan taman, ruang untuk aktivitas sirkulasi, ruang untuk aktivitas penanaman, dan ruang-ruang lainnya (Gambar 6). Pekerjaan ini dilakukan untuk mempermudah pekerjaan grading (Strom et al., 2009). Grading merupakan pekerjaan pembentuk lahan untuk mewadahi aktivitas-aktivitas yang ingin dilakukan di taman jalur hijau tersebut.

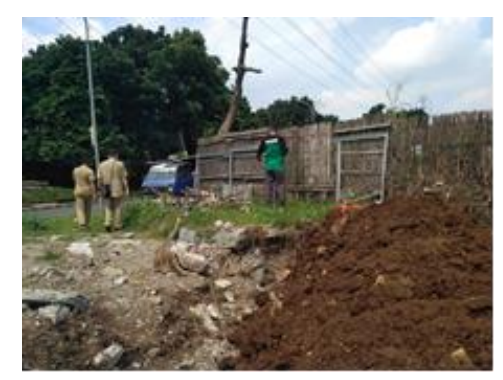

Gambar 6. Pekerjaan pembersihan tapak, pengukuran tapak, pengukuran ruang aktivitas-aktivitas Sumber: Dokumen pribadi (2020)

Pekerjaan yang selanjutnya adalah pekerjaan penanaman. Pekerjaan penanaman didahului dengan pekerjaan pengurugan tanah dan pemberian pupuk kompos. Pekerjaan penanaman dimulai dengan penanaman pohon, lalu penanaman semak dan perdu, penanaman penutup tanah dan diakhiri dengan penanaman rumput (Gambar 7, 8, dan 9). 


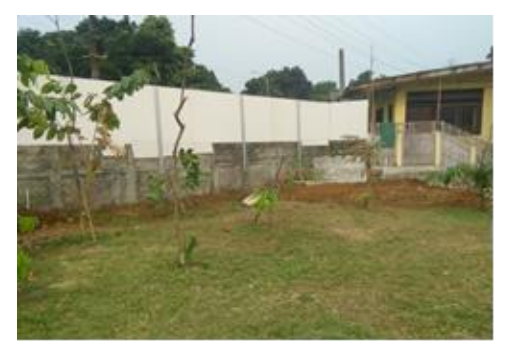

Gambar 7. Pekerjaan penanaman pohon

Sumber: Dokumen pribadi (2020)

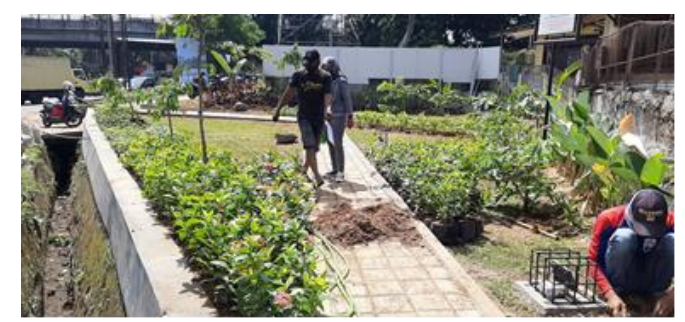

Gambar 8. Pekerjaan penanaman semak dan perdu Sumber: Dokumen pribadi (2020)

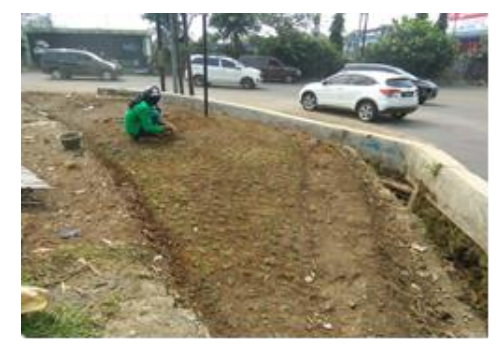

Gambar 9. Pekerjaan penanaman rumput

Sumber: Dokumen pribadi (2020)

Pekerjaan hardscape terdiri dari 1) pekerjaan edging pembatas, 2) pekerjaan jalan setapak, 3) pekerjaan pemasangan lampu taman, 4) pekerjaan perapihan jalan akses, 5) pekerjaan perapihan sumur, 6) pekerjaan mesin/pompa air, rumah pompa, kran air dan pipa air include instalasi, dan 7) pekerjaan pot beton minimalis fin.aci profil $1 \mathrm{~m} \times 1 \mathrm{~m} \times 1 \mathrm{~m}$. Pekerjaan hardscape diawali dengan pekerjaan pembuatan pembatas. Pekerjaan pembatas ini merupakan pekerjaan pemasangan pembatas antara ruang penanaman dengan ruang jalan setapak, pemasangan pembatas antara ruang penanaman dengan saluran drainase, pemasangan pembatas antara ruang jalan setapak dengan ruang sirkulasi kendaraan bermotor (Gambar 10).

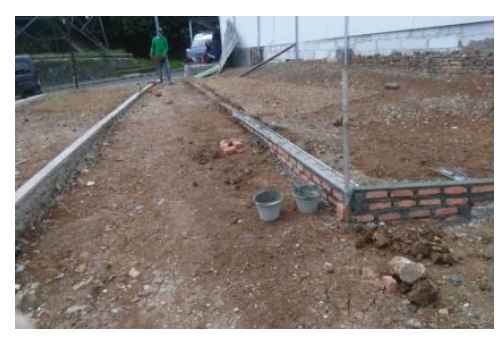

(a) 


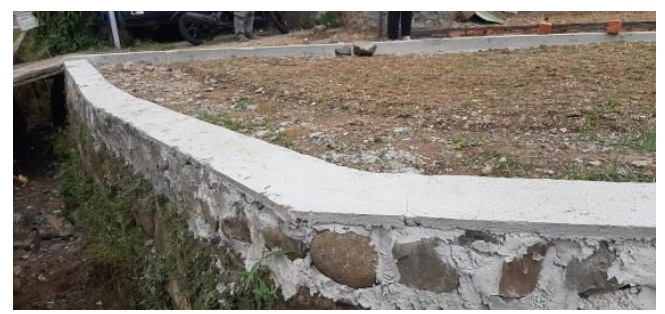

(b)

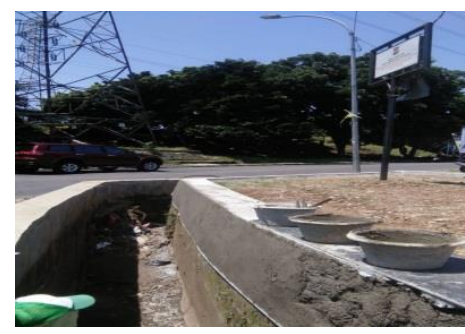

(c)

Gambar 10. Pekerjaan pemasangan pembatas antara ruang sirkulasi dan ruang penanaman (a) pekerjaan pemasangan pembatas antara ruang penanaman dan drainase (b), dan pekerjaan pemasangan pembatas antara ruang drainase dan ruang sirkulasi jalan $\odot$

Sumber: Dokumen pribadi (2020)

Pekerjaan selanjutnya adalah pekerjaan jalan setapak. Jalan tapak dibuat selebar $\pm 2 \mathrm{~m}$. Pekerjaan ini didahului dengan pemadatan tanah dasar, lalu penebaran abu batu, perataan abu batu, pemasangan paving block, dan diakhiri dengan perataan permukaan paving block dan pengisian celah antar paving block dengan abu batu (Gambar 11).

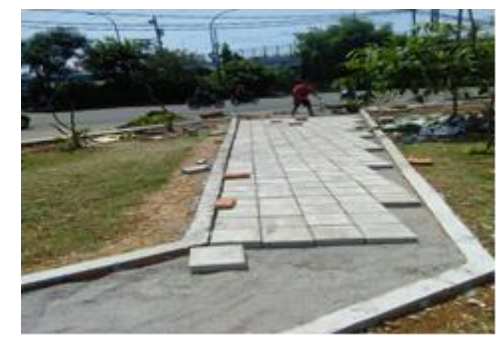

Gambar 11. Pekerjaan pemasangan paving block

Sumber: Dokumen pribadi (2020)

Pekerjaan lampu merupakan pemasangan jaringan lampu sorot bawah pohon dan pemasangan lampu serta penyambungan listrik ke panel listrik. Pemasangan lampu sorot bertujuan menampilkan kesan estetika di malam hari (Gambar 12).

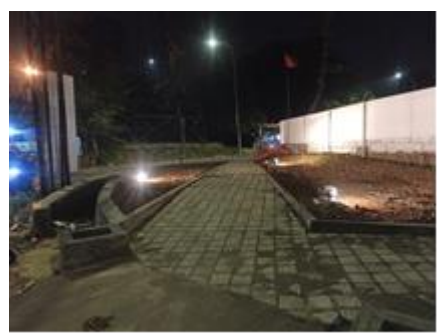

Gambar 12. Pekerjaan pemasangan lampu sorot

Sumber: Dokumen pribadi (2020) 
Pekerjaan pembuatan sumur bertujuan untuk adanya sumber air untuk penyiraman tanaman dan pembersihan jalan setapak dan fasilitas lainnya. Sumur yang dibuat sedalam $40 \mathrm{~m}$ dan disediakan rumah pompa serta instalasi jaringan pipa untuk penyiraman (Gambar 13).

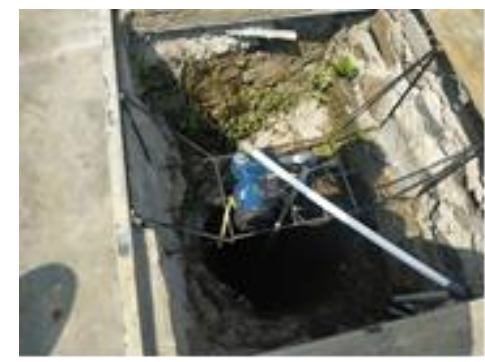

Gambar 13. Pekerjaan pemasangan lampu sorot Sumber: Dokumen pribadi (2020)

Pekerjaan pembuatan pot beton bertujuan untuk estetika taman dan menempatkan tanaman yang indah secara individu. Pot tersebut sebanyak 2 buah (Gambar 14).

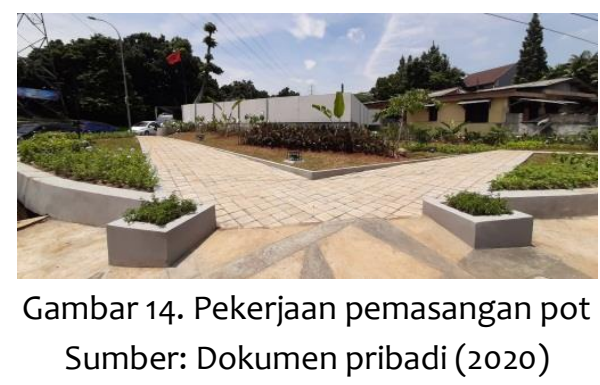

\section{Pengawasan Pelaksanaan Pembangunan Taman Sudut Kota, Jalur Hijau Jl. Padi}

Pembangunan taman sudut kota ini dilakukan selama 30 hari kalender, mulai tanggal 19 Agustus 2020 hingga 17 September 2020. Tenaga kerja yang digunakan untuk pekerjaan ini adalah 1 orang pengawas lapang, 1 orang pelaksana, 1 orang tenaga logistik, 1 orang tenaga administrasi, 1 orang mandor, 3 orang tukang, dan 2 orang pembantu pekerja. Pembangunan taman sudut kota ini bekerja dengan prinsip pembangunan yang memiliki bahan yang bermutu, penggunaan yang efektif, dan biaya yang seefisien mungkin. Pekerjaan ini dilandasi oleh kontrak harga satuan pelaksanaan pekerjaan. Menurut Ervianto (2005), kontrak harga satuan adalah kontrak pengadaan barang dan jasa atas penyelesaian seluruh pekerjaan dalam batas waktu tertentu.

Pelaksanaan pekerjaan mengalami percepatan dari rencana pelaksanaan pekerjaan yang dibuat. Rekapitulasi prestasi mingguan dapat dilihat pada Tabel 1.

Tabel 1. Rekapitulasi prestasi mingguan

\begin{tabular}{|c|l|c|c|c|c|c|}
\hline \multirow{2}{*}{ No } & \multirow{2}{*}{ Item Kegiatan } & \multicolumn{5}{|c|}{ Bobot Prestasi per minggu (\%) } \\
\cline { 3 - 7 } & & I & II & III & IV & V \\
\hline 1 & Rencana Pekerjaan & 7,05 & 20,08 & 43,58 & 73,25 & 100 \\
\hline 2 & Pelaksanaan Pekerjaan & 8,80 & 27,97 & 62,32 & 96,35 & 100 \\
\hline 3 & Percepatan & 1,75 & 7,89 & 18,74 & 23,10 & 0 \\
\hline
\end{tabular}

Berdasarkan data tersebut di atas, pekerjaan pelaksanaan pembangunan taman sudut kota jalur hijau Jl, Padi setiap minggunya lebih cepat dari yang direncanakan (Gambar 15). Pengawasan 
berkala setiap minggunya salah satu kegiatan yang mendorong percepatan pekerjaan tersebut sehingga dapat selesai tepat waktu.

\begin{tabular}{|c|c|c|c|c|c|c|c|c|c|}
\hline \multirow{3}{*}{ no } & & \multirow{3}{*}{ JENIS PEKERJAAN } & \multirow{3}{*}{ вовот \% } & \multicolumn{5}{|c|}{ HARI DAN MINGGU KE- } & \multirow{3}{*}{ KETERANGAN } \\
\hline & & & & 1 & 2 & 3 & 4 & 5 & \\
\hline & & & & $1-7$ & $8-14$ & $15-21$ & $22-28$ & $29-30$ & \\
\hline \multirow[t]{2}{*}{1} & PEKERJAAN P & IAPAN & & & & & & & \\
\hline & & TOTAL PEKERJAAN PERSIAPAN & 9.83 & 1.97 & 1.97 & 1.97 & 1.97 & 1.97 & \\
\hline \multirow[t]{2}{*}{ II } & PEKERJAAN P & ANAMAN & & & & & & & \\
\hline & & TOTAL PEKERJAAN PENANAMAN & 45.36 & - & - & & 15.12 & 15.12 & \\
\hline \multirow[t]{2}{*}{ IIII } & PEKERJAAN & DSCAPE & & & & & & & \\
\hline & & TOTAL PEKERJAAN HARDSCAPE & 44.81 & $\rightleftharpoons$ & 5.98 & 6.42 & 12.59 & 9.67 & \\
\hline \multicolumn{3}{|c|}{ BOBOT RENCANA } & 100.00 & 1.97 & 7.95 & 23.51 & 29.68 & 26.76 & \\
\hline \multicolumn{3}{|c|}{ AKUMULASI BOBOT RENCANA } & & 7.05 & 20.08 & 43.58 & 73.25 & 100.00 & \\
\hline \multicolumn{3}{|c|}{ REALISASI BOBOT RENCANA (\%) } & & 8.80 & 19.17 & 35.33 & 36.21 & 0.50 & \\
\hline \multicolumn{3}{|c|}{ REALISASI AKUMULASI BOBOT RENCANA (\%) } & & 8.80 & 27.97 & 62.32 & 96.35 & 100.00 & \\
\hline & DEVIASI (\%) & & & -1.75 & -7.89 & -18.74 & -23.10 & 0.00 & \\
\hline \multirow{2}{*}{\multicolumn{3}{|c|}{ KETERANGAN : }} & \multirow{2}{*}{\multicolumn{2}{|c|}{ Perencanaan }} & & & & & \\
\hline & & & & & & & & & \\
\hline & & $\longrightarrow$ & \multicolumn{3}{|c|}{ Realisasi berdasarkan monitoring dilapangan } & & & & \\
\hline
\end{tabular}

Gambar 15. Grafik realisasi pelaksanaan pekerjaan dan percepatannya

Pelaksanaan pekerjaan ini mengalami kemajuan setiap minggunya. Pada minggu pertama : 1) pekerjaan persiapan telah dilakukan $57,19 \%$ dan 2) pekerjaan hardscape telah dilakukan 7,09 \%. Pekerjaan penanaman pada minggu pertama belum dilakukan (Tabel 2). Pada minggu kedua : 1) pekerjaan persiapan mengalami kemajuan sebesar 94,91\% dan 2) pekerjaan hardscape mengalami kemajuan sebesar 41,59\%. Di minggu kedua pekerjaan penanaman belum dilakukan (Tabel 3). Pada minggu ketiga : 1) pekerjaan persiapan belum mengalami kemajuan, 2) pekerjaan penanaman telah dilakukan 59,84\%, dan 3) pekerjaan hardscape mengalami kemajuan sebesar 57,67\% (Tabel 4). Pada minggu keempat : 1) pekerjaan persiapan belum mengalami kemajuan, 2) pekerjaan penanaman telah diselesaikan $100 \%$, dan 3) pekerjaan hardscape mengalami kemajuan sebesar 92, 98\% (Tabel 5). Pada minggu kelima : 1) pekerjaan persiapan telah diselesaikan $100 \%, 2)$ pekerjaan penanaman telah diselesaian $100 \%$, dan 3) pekerjaan hardscape telah diselesaikan 100\% (Tabel 6). Di awal minggu terutama minggu pertama dan kedua, pekerjaan ini mendahulukan pekerjaan persiapan dan pekerjaan hardscape. Hal ini bertujuan untuk memudahkan pekerjaan penanaman dan perlindungan terhadap saluran drainase, cepat terselesaikan. Pada minggu kedua pekerjaan penanaman telah dimulai dan mencapai lebih dari $50 \%$ dari total pekerjaan penanaman dan pekerjaan hardscape juga mengalami kemajuan yang cukup berarti. Pada minggu keempat, pekerjaan hardscape dapat mencapai lebih dari $50 \%$ untuk memberikan kemudahan akses dan pemeliharaan tanaman yang telah ditanam. Pada minggu keempat, pekerjaan penanaman terselesaikan seluruh dan pekerjaan hardscape mencapai lebih dari $90 \%$, sehingga tujuan untuk membuat taman sudut kota jalur hijau J. Padi dapat tercapai dengan baik. Pada minggu seluruh pekerjaan $100 \%$ terselesaikan dengan baik. 
20 Pengawasan Teknis Penataan Taman Jalur Hijau di Kecamatan Bogor Timur, Kota Bogor Jawa Barat

Tabel 2. Rekapitulasi pekerjaan pada minggu pertama

\begin{tabular}{|c|c|c|c|c|c|c|c|}
\hline \multirow{2}{*}{ No. } & \multirow{2}{*}{\multicolumn{2}{|c|}{ NAMA BARANG }} & \multirow{2}{*}{ ВОВОт \% } & \multicolumn{3}{|c|}{ ВОВОт \% } & \multirow{2}{*}{$\begin{array}{c}\text { PRESENTASE KEMAJUAN } \\
\text { PEKERJAAN \% }\end{array}$} \\
\hline & & & & Minggu Lalu & Minggu Ini & s/d Minggu Ini & \\
\hline \multirow[t]{2}{*}{$\mathrm{I}$} & \multicolumn{2}{|c|}{ PEKERJAAN PERSIAPAN } & & & & & \\
\hline & & TOTAL PEKERJAAN PERSIAPAN & 9.83 & - & 5.62 & 5.62 & 57.19 \\
\hline \multirow[t]{2}{*}{ II } & PEKERJAAN PENAN & MAN & & & & & \\
\hline & & TOTAL PEKERJAAN PENANAMAN & 45.36 & - & - & - & - \\
\hline \multirow[t]{3}{*}{ IIII } & PEKERJAAN HARDS & & & & & & \\
\hline & & & 44.81 & - & 3.18 & 3.18 & 7.09 \\
\hline & & TOTAL PEKERJAAN HARDSCAPE & 100.00 & - & 8.80 & 8.80 & 8.80 \\
\hline \multicolumn{3}{|c|}{ PRESTASI KEMAJUAN PEKERJAAN MINGGU LALU \% } & 0.00 & $\%$ & & & \\
\hline \multicolumn{3}{|c|}{ PRESTASI KEMAJUAN PEKERJAAN MINGGU INI } & 8.80 & $\%$ & \multicolumn{2}{|c|}{ Waktu Pelaksanaan } & $30 \mathrm{HK}$ \\
\hline \multicolumn{3}{|c|}{ RENCANA PEKERJAAN S/D MINGGU INI } & 7.05 & $\%$ & \multicolumn{2}{|c|}{ Waktu yang telah digunakan } & $7 \mathrm{HK}$ \\
\hline \multicolumn{2}{|c|}{ DEVIASI SESUAI JADWAL } & & -1.75 & $\%$ & \multicolumn{2}{|c|}{ Sisa Waktu Pelaksanaan } & $23 \mathrm{HK}$ \\
\hline
\end{tabular}

Tabel 3. Rekapitulasi pekerjaan pada minggu kedua

\begin{tabular}{|c|c|c|c|c|c|c|}
\hline \multirow{2}{*}{ No. } & \multirow{2}{*}{ NAMA BARANG } & \multirow{2}{*}{ Вовот \% } & \multicolumn{3}{|c|}{ вовот \% } & \multirow{2}{*}{$\begin{array}{c}\text { PRESENTASE KEMAJUAN } \\
\text { PEKERJAAN \% }\end{array}$} \\
\hline & & & Minggu Lalu & Minggu Ini & s/d Minggu Ini & \\
\hline \multirow[t]{2}{*}{1} & PEKERJAAN PERSIAPAN & & & & & \\
\hline & TOTAL PEKERJAAN PERSIAPAN & 9.83 & 5.62 & 3.71 & 9.33 & 94.91 \\
\hline \multirow[t]{2}{*}{ II } & PEKERJAAN PENANAMAN & & & & & \\
\hline & TOTAL PEKERJAAN PENANAMAN & 45.36 & - & - & - & - \\
\hline \multirow[t]{3}{*}{ III } & PEKERJAAN HARDSCAPE & & & & & \\
\hline & & 44.81 & 3.18 & 15.46 & 18.64 & 41.59 \\
\hline & TOTAL PEKERJAAN HARDSCAPE & 100.00 & 8.80 & 19.17 & 27.97 & 27.97 \\
\hline \multicolumn{2}{|r|}{ PRESTASI KEMAJUAN PEKERJAAN MINGGU LALU \% } & 8.80 & $\%$ & & & \\
\hline \multicolumn{2}{|r|}{ PRESTASI KEMAJUAN PEKERJAAN MINGGU INI } & 27.97 & $\%$ & \multicolumn{2}{|c|}{ Waktu Pelaksanaan } & $30 \mathrm{HK}$ \\
\hline \multicolumn{2}{|r|}{ RENCANA PEKERJAAN S/D MINGGU INI } & 20.08 & $\%$ & \multicolumn{2}{|c|}{ Waktu yang telah digunakan } & $14 \mathrm{HK}$ \\
\hline \multicolumn{2}{|c|}{ DEVIASI SESUAI JADWAL } & -7.89 & $\%$ & \multicolumn{2}{|c|}{ Sisa Waktu Pelaksanaan } & $16 \mathrm{HK}$ \\
\hline
\end{tabular}

Tabel 4. Rekapitulasi pekerjaan pada minggu ketiga

\begin{tabular}{|c|c|c|c|c|c|c|}
\hline \multirow{2}{*}{ No. } & \multirow{2}{*}{ NAMA BARANG } & \multirow{2}{*}{ Вовот \% } & \multicolumn{3}{|c|}{ ВОВОт \% } & \multirow{2}{*}{$\begin{array}{c}\text { PRESENTASE KEMAJUAN } \\
\text { PEKERJAAN \% }\end{array}$} \\
\hline & & & Minggu Lalu & Minggu Ini & s/d Minggu Ini & \\
\hline \multirow[t]{2}{*}{1} & PEKERJAAN PERSIAPAN & & & & & \\
\hline & TOTAL PEKERJAAN PERSIAPAN & 9.83 & 9.33 & 0.00 & 9.33 & 94.91 \\
\hline \multirow[t]{2}{*}{ II } & PEKERJAAN PENANAMAN & & & & & \\
\hline & TOTAL PEKERJAAN PENANAMAN & 45.36 & - & 27.14 & 27.14 & 59.84 \\
\hline \multirow[t]{3}{*}{ III } & PEKERJAAN HARDSCAPE & & & & & \\
\hline & & 44.81 & 18.64 & 8.18 & 25.85 & 57.67 \\
\hline & TOTAL PEKERJAAN HARDSCAPE & 100.00 & 27.97 & 35.33 & 62.32 & 62.32 \\
\hline
\end{tabular}

\begin{tabular}{|l|l|l|l|}
\hline PRESTASI KEMAJUAN PEKERJAAN MINGGU LALU \% & $27.97 \%$ & \\
\hline PRESTASI KEMAJUAN PEKERJAAN MINGGU INI & $62.32 \%$ & Waktu Pelaksanaan \\
\hline RENCANA PEKERJAAN S/D MINGGU INI & $\mathbf{4 3 . 5 8 \%}$ & Waktu yang telah digunakan \\
\hline DEVIASI SESUAI JADWAL & $-18.74 \%$ & Sisa Waktu Pelaksanaan \\
\hline
\end{tabular}


Tabel 5. Rekapitulasi pekerjaan pada minggu keempat

\begin{tabular}{|c|c|c|c|c|c|c|}
\hline \multirow{2}{*}{ No. } & \multirow[b]{2}{*}{ NAMA BARANG } & \multirow[b]{2}{*}{ ВОВОт \% } & \multicolumn{3}{|c|}{ ВОВОТ \% } & \multirow{2}{*}{$\begin{array}{c}\text { PRESENTASE KEMAJUAN } \\
\text { PEKERJAAN \% }\end{array}$} \\
\hline & & & Minggu Lalu & Minggu Ini & s/d Minggu Ini & \\
\hline \multirow[t]{2}{*}{$\mathrm{I}$} & PEKERJAAN PERSIAPAN & & & & & \\
\hline & TOTAL PEKERJAAN PERSIAPAN & 9.83 & 9.33 & 0.00 & 9.33 & 94.91 \\
\hline \multirow[t]{2}{*}{ II } & PEKERJAAN PENANAMAN & & & & & \\
\hline & TOTAL PEKERJAAN PENANAMAN & 45.36 & 27.14 & 18.21 & 45.36 & 100.00 \\
\hline \multirow[t]{3}{*}{ III } & PEKERJAAN HARDSCAPE & & & & & \\
\hline & & 44.81 & 23.67 & 17.99 & 41.67 & 92.98 \\
\hline & TOTAL PEKERJAAN HARDSCAPE & 100.00 & 60.15 & 36.21 & 96.35 & 96.35 \\
\hline
\end{tabular}

\begin{tabular}{|c|c|c|c|}
\hline PRESTASI KEMAJUAN PEKERJAAN MINGGU LALU \% & $60.15 \%$ & & \\
\hline PRESTASI KEMAJUAN PEKERJAAN MINGGU INI & $96.35 \%$ & Waktu Pelaksanaan & $30 \mathrm{HK}$ \\
\hline RENCANA PEKERJAAN S/D MINGGU INI & $73.25 \%$ & Waktu yang telah digunakan & $28 \mathrm{HK}$ \\
\hline DEVIASI SESUAI JADWAL & $-23.10 \%$ & Sisa Waktu Pelaksanaan & $2 \mathrm{HK}$ \\
\hline
\end{tabular}

Tabel 6. Rekapitulasi pekerjaan pada minggu kelima

\begin{tabular}{|c|c|c|c|c|c|c|}
\hline \multirow{2}{*}{ No. } & \multirow{2}{*}{ NAMA BARANG } & \multirow{2}{*}{ Вовот \% } & \multicolumn{3}{|c|}{ ВОВот \% } & \multirow{2}{*}{$\begin{array}{c}\text { PRESENTASE KEMAJUAN } \\
\text { PEKERJAAN \% }\end{array}$} \\
\hline & & & Minggu Lalu & Minggu Ini & s/d Minggu Ini & \\
\hline \multirow[t]{2}{*}{$\mathrm{I}$} & PEKERJAAN PERSIAPAN & & & & & \\
\hline & TOTAL PEKERJAAN PERSIAPAN & 9.83 & 9.33 & 0.50 & 9.83 & 100.00 \\
\hline \multirow[t]{2}{*}{ II } & PEKERJAAN PENANAMAN & & & & & \\
\hline & TOTAL PEKERJAAN PENANAMAN & 45.36 & 45.36 & - & 45.36 & 100.00 \\
\hline \multirow[t]{3}{*}{ III } & PEKERJAAN HARDSCAPE & & & & & \\
\hline & & 44.81 & 38.75 & 0.00 & 44.81 & 100.00 \\
\hline & TOTAL PEKERJAAN HARDSCAPE & 100.00 & 93.44 & 0.50 & 100.00 & 100.00 \\
\hline \multicolumn{2}{|r|}{ PRESTASI KEMAJUAN PEKERJAAN MINGGU LALU \% } & 93.44 & $\%$ & & & \\
\hline \multicolumn{2}{|r|}{ PRESTASI KEMAJUAN PEKERJAAN MINGGU INI } & 100.00 & $\%$ & \multicolumn{2}{|c|}{ Waktu Pelaksanaan } & $30 \mathrm{HK}$ \\
\hline \multicolumn{2}{|r|}{ RENCANA PEKERJAAN S/D MINGGU INI } & 100.00 & $\%$ & \multicolumn{2}{|c|}{ Waktu yang telah digunakan } & $30 \mathrm{HK}$ \\
\hline \multicolumn{2}{|c|}{ DEVIASI SESUAI JADWAL } & 0.00 & & \multicolumn{2}{|c|}{ Sisa Waktu Pelaksanaan } & $\mathbf{O H K}$ \\
\hline
\end{tabular}

Percepatan pekerjaan dengan jumlah tenaga kerja yang mencukup dilakukan dengan penggunaan waktu yang seefisien mungkin. Biaya yang dikeluarkan untuk pembangunan taman sudut kota ini cukup terpenuhi. Mutu pekerjaan dan bahan-bahan yang digunakan baik sesuai dengan keinginan dari pemberi pekerjaan. Bahan-bahan yang digunakan telah memenuhi persyaratan dan pengujian mutu terutama pada bahan-bahan hardscape. Tanaman-tanaman yang digunakan berada dalam kondisi yang baik saat penanaman. Pemenuhan nilai fungsi dan estetika dari taman yang dibangun terpenuhi dengan hadirnya elemen-elemen taman seperti lampu sorot, tanaman yang bernilai estetika, fungsi hadirnya keanekaragaman tanaman seperti penyedia oksigen dan perendam suhu dan kelembaban yang ada di lokasi tersebut, penempatan jalur sirkulasi yang memudahkan pergerakan, perlindungan terhadap saluran drainase, dan penyediaan sarana penyiraman. Taman sudut kota ini secara keseluruhan mampu menyediakan sarana bagi masyarakat untuk tempat berkumpul, beristirahat dan bermain. Pada akhir pekerjaan, dilakukan pembersihan dan perapihan terhadap pekerjaan. Pada akhirnya pelaksana dan pengawas serta pihak pemberi pekerjaan bersamasama untuk mewujudkan taman sudut kota ini yang berfungsi dan bernilai estetika. 


\section{PENUTUP}

Simpulan

Pekerjaan pengawasan memastikan bahwa pekerjaan menggunakan bahan-bahan yang bermutu baik, menggunakan tenaga yang ahli dan terampil, dan tepat waktu. Selain itu juga penggunaan biaya yang efisien dengan pengeluaran yang tepat sasaran. Kepastian mutu yang baik, efisien, dan efektif dalam menyelesaian proses pembangunan taman sudut kota ini diperlukan pemberi pekerjaan sebagai bagian dari pertanggungjawaban ke masyarakat.

Pekerjaan pembangunan taman sudut kota jalur hijau Jl. Padi mengalami percepatan yang cukup signifikan, terutama pada minggu ketiga dan keempat. Di minggu pertama meskipun mengalami percepatan pekerjaan dari yang direncanakan, namun belum terlihat signifikan. Percepatan pekerjaan mulai menanjak berdasarkan grafik progress pekerjaan mulai terlihat pada saat menyelesaikan pekerjaan di minggu kedua.

Pekerjaan pembangunan taman memerlukan kerjasama yang baik dari pelaksana pekerjaan, pengawas pekerjaan, dan pemberi kerja. Pengawasan ideal dilakukan untuk menjaga agar hasil yang dilakukan sesuai dengan desain yang diberikan oleh pemberi tugas. Pengawasan juga harus dapat menjamin bahwa pekerjaan terselesaikan dengan baik dan tepat waktu. Dalam hal ini dibutuhkan juga peran pemberi pekerjaan agar dapat mendorong dan mengontrol apa yang diinginkan dari perencanaan yang dilakukan.

\section{Saran}

Untuk mendapatkan hasil yang baik dalam pembangunan taman maka :

1. Perlunya pelaksana pekerja menggunakan tenaga ahli untuk mengarahkan pekerjaan di lokasi dan menggunakan tenaga terampil agar pekerjaan terlaksana dengan baik.

2. Perlunya keterpaduan pekerjaan antara pelaksana, pengawas dan pemberi pekerjaan untuk memastikan bahwa pekerjaan sesuai dengan desain yang dibuat dan jadwal yang direncanakan.

3. Perlu pemberi pekerja melakukan kontrol dengan baik untuk memastikan apa yang diinginkan di dalam desain dalam dilaksanakan dengan baik

\section{DAFTAR PUSTAKA}

Booth, N.K. (1983). Basic Element of Landscape Architecture Design. Illinois, US: Waveland Press, Inc. Carpenter, P.L., Walker D., Lanphear O. (1975). Plants in The Landscape. San Fransisco, US: W.H. Freeman and Co. 418 hal.

Ervianto, W.I. (2005). Manajemen Proyek Konstruksi. Yogyakarta, ID: Penerbit Andi Offset.

Gustiana, R. (2017). Analisis Standarisasi Pengawasan Terhadap Pembangunan Kawasan Taman Kota. Jurnal Mozaik Vol.IX Edisi 2 (hal.109-115), E-ISSN:2614-8390 P-ISSN:1858-1269

Motloch J.I. (2001). Introduction to Landscape Design. Canada, US: John Wiley \& Sons Inc.

Munandar, A., \& Kusumoarto, A. (2020). Pengantar Menuju Riset Manajemen Lanskap. In A. Munandar, A. Kusumoarto, \& A. Gunawan (eds), Manajemen Lanskap : Tinjauan Riset Manajemen Lanskap dan Lingkungan (hal. 1-5). Bogor, ID: IPB Press.

Starke, B.W., \& Simonds J.O. (2013). Landscape Architecture : A Manual of Environmental Planning and Design. United State of America, US: McGraw-Hill Education.

Strom, S., Nathan, K., \& Woland, J. (2009). Site Engineering for Landscape Architects. Canada, US: John Wiley \& Sons Inc. 